\title{
Multi-disciplinary investigation of 19th century European settlement of the Willunga Plains, South Australia
}

\section{Tim Denham}

School of Geography and Environmental Science, Monash University, Clayton, Victoria

Tim.Denham@arts.monash.edu.au

\section{Carol Lentfer}

University of Queensland, St. Lucia, Queensland

\section{Ellen Stuart}

Flinders University, Adelaide, South Australia

\section{Sophia Bickford}

Monash University, Clayton, Victoria

\section{Cameron Barr}

University of Adelaide, Adelaide, South Australia

\section{Introduction}

The arrival of Europeans in Australia has been described as an 'apocalyptic event for Australian ecosystems' (Adamson and Fox 1982:110). It is generally assumed that subsequent transformations of Australian biota and landscapes have been more dramatic than those made by Aborigines over tens of millennia (Young 1996:72). However, there is limited scientific data with meaningful temporal resolution (i.e. decadal or subdecadal) that shows the nature, extent and rate of transformation concomitant with European colonisation of landscapes in Australia (e.g. Dodson et al. 1994a, 1994b; Gale et al. 1995; Mooney 1997; Haberle et al. 2006; see 
review in Dodson and Mooney 2002).

There are several comprehensive reviews of the impacts of European colonisation and agriculture on the Australian landscape (Adamson and Fox 1982; Hobbs and Hopkins 1990; Young 1996). Until recently, there was a dearth of high-resolution records that tracked the environmental effects of European colonisation and changing land uses through time (Lunt 2002). Most palaeoenvironmental studies of landscape change in Australia have tended to rely heavily on palynological and microcharcoal data, which have proven to be problematic (Kershaw et al. 1994) and remain to be more fully explored (Dodson and Mooney 2002:455). Some studies, especially more recent ones, have been broadened to include a wider range of palaeoecological proxies and multi-proxy research (e.g. Lentfer et al. 1997; Haberle et al. 2006; Bowdery 2007).

In an attempt to address these issues, a multi-disciplinary study was undertaken to reconstruct past environments at the California Road Wetland in the Ingleburn Creek catchment on the Willunga Plains. The research was devised to address three inter-related themes: first, to assemble a high-resolution palaeoecological record for the 19th century European colonisation of the Willunga Plains, thereby complementing similar investigations on the Fleurieu Peninsula (Bickford 2001; Bickford and Gell 2005; Bickford et al. 2008); second, to use historical background research to reconstruct the transformation of the Willunga landscape during this period (Stuart 2005, 2006), and to synthesise this historical reconstruction with the palaeoecological record; and, third, to assess the value of multi-proxy palaeoecological investigations for understanding environmental change during the recent past (i.e. past 250 years), with a particular focus on the complementarity of pollen and phytolith analyses for vegetation reconstruction and the identification of recently introduced exotics. In other words, the project was originally intended to address two sets of issues: substantive, i.e. to construct a high-resolution, multi-proxy record of landscape transformation during European colonisation; and, methodological, i.e. to integrate historical-palaeoecological reconstructions and assess the complementarity of pollen-phytolith analyses.

\section{The Willunga Plains}

... level country stretching for miles; it is of the richest character, and is covered with so long and thick an herbage that it is quite laborious to walk through it. There are numerous woods, of a very open description and some spots where the scenery resembles an Englishman's park... Here was a most luxuriant soil, in some places level and commanding an extensive view; in others having vistas through rows of elegant trees; at others the view is bounded by boldly shaped hills intersected by deep ravines ... (John Morphett, letter home, 1836, describing the plains behind Aldinga while searching South Australia for new places for colonial settlement; cited in Vaudrey and Vaudrey 1991:10).

The Willunga Basin comprises 100,000 ha of relatively low-lying land defined by an escarpment of the Mount Lofty Ranges to the south and east, and includes the Willunga Plains extending west to the coast (Figure 1 upper). On April 13, 1844, the Adelaide Observer described surface water on the plains to be scarce, but in 'winter almost every glen and ravine has water in it; but the little rivulets soon run to waste, and after a few warm days they dry up' (unattributed, in Stuart 2005:18). As well as seasonal variability, there was great spatial variability in the availability of water on the plains; some settlers' wells were sunk to 180 feet, while others to only 10 feet (Dunstan 1977:20; see Newman and Lawrence 1999).

Surface soils across the Willunga Basin were described by 19th century surveyors as varying 
greatly in texture, from sands, sandy loams, black and chocolate loams to yellow clays. The floor of the basin contains 'gilgai' soils, also referred to as 'Bay-of-Biscay'soil (Overton 1993:14). Soils in the region tend to be alkaline and deficient in a wide range of mineral elements, including phosphorus $(\mathrm{P})$, nitrogen $(\mathrm{N})$, zinc $(\mathrm{Zn})$, molybdenum $(\mathrm{Mo})$, sulphur $(\mathrm{S})$ and manganese $(\mathrm{Mn})$ (Northcote 1976:65). Despite these deficiencies, the plains have long-been perceived as fertile and well-suited to horticultural and pastoral uses (e.g. Hawker 1901: 52).

The Willunga Plains have an average rainfall of ca. $650 \mathrm{~mm}$, with highest average rainfall from May to August (ca. $88 \mathrm{~mm}$ per month) and lowest average rainfall from December to February (less than $25 \mathrm{~mm}$ per month) (Bureau of Meteorology 1985). Seasonally, the coolest and wettest months occur during winter, while summer is generally hotter and drier, with high evapotranspiration, low relative humidity and soil water deficit.

Before European settlement, the Willunga Plains comprised open woodlands dominated by Eucalyptus leucoxolyn, E. odorata and Allocasuarina verticillata, with a herbaceous understorey of grasses, including perennial grass (Themeda australis) and scattered low shrubs of Acacia spp., Callitris spp. and Melaleuca spp. (Specht 1972:34; see Newman 1994). The uplands of the watershed supported sclerophyll forests of E. obliqua and E. baxteri on the steep westward slopes, with associated shrub understorey, including species in the Myrtaceae, Protaceae and Xanthorrhoeaceae families (Specht 1972:34; Bickford and Gell 2005:201). Following survey in 1839, the plains underwent settlement and transformation into an agricultural landscape. Small pockets of native vegetation communities only survive in some wetlands, gullies and along the top of Sellicks Hill Range.

\section{A brief history of European settlement}

The Aborigines - the Kaurna - who lived, foraged and hunted in the region, survived by exploiting food and water resources, of which newly arrived European colonists were largely ignorant. Unfortunately, there is no detailed archaeological information of Kaurna subsistence on the Willunga Plains before European settlement.

In 1839, James Hawker, Colony Assistant Surveyor, was assigned to survey the road from 'Horseshoe' (Noarlunga) to Willunga in a 'special survey' of District C (Hawker 1901). This signalled the first official movement of settlers to the southern region, although unsanctioned and undocumented movements may have occurred earlier (see Bickford 2001; also see Gale and Haworth 2002). The Hundred of Willunga was established as a farming region that came to include the townships of Willunga, Aldinga and McLaren Vale. By 1841, 137 Europeans had already settled in the district and the population consistently rose over the following decades (Lewis 1936).

Clearing the land was a normal activity of farm work and, because demand for timber was high for construction and other uses, tree-felling proved a lucrative occupation for some (Williams 1992:27). Licensed timber-cutters denuded the hills and plains of large eucalypts and shrubs, thereby assisting property owners to clear the land (Dunstan 1977:10). No type of timber was left untouched; even the drooping branches and leaves of Allocasuarina verticillata were cut to provide fodder for cattle and sheep (Bickford 2001:33). Land was cleared of less useful timber by ring-barking and burning.

The first settlers on the plains established mixed farms adjacent to water springs and permanent water sources. Cattle and sheep were raised and crops of wheat, barley, oats, maize and potatoes were grown with varying success. Santich (1998:94) and British Parliamentary Papers (BPP 1970 [1843]:101) provide an account of one settler's early years. After arriving in McLaren Vale in January 1840, Charles Hewett and his family took up their sections, named 'Oxenbury Farm', and improved them with post and rail fencing, sheep pens, a dairy and 

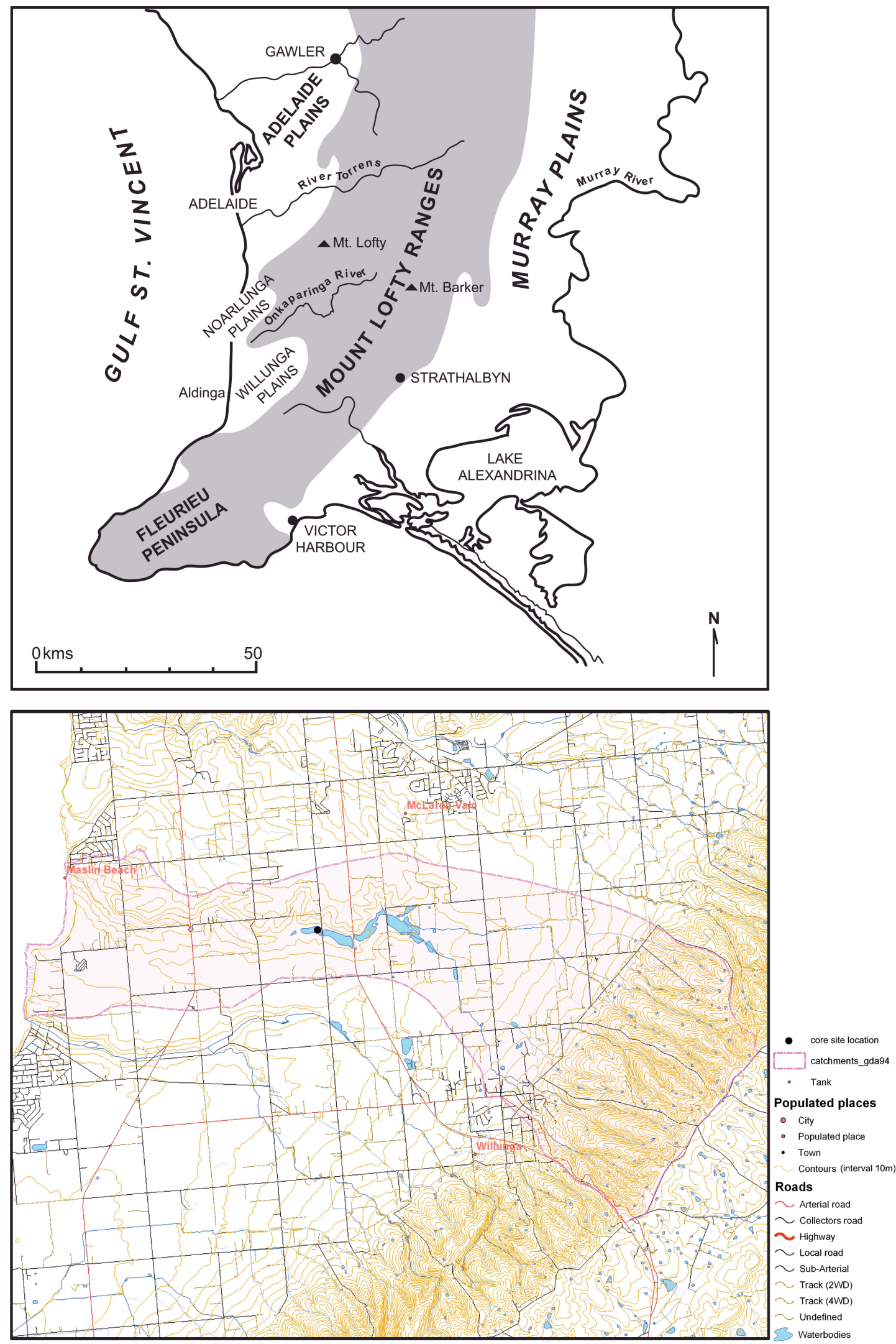

Figure 1. Upper: Map of the Willunga Plains in the Adelaide region of South Australia. Lower: Location of the California Road Wetland coring site on a map of Maslin's Creek catchment (based on information provided by Planning SA and produced by Adelaide Hills Face Zone project, Flinders University, South Australia). 
stockyards (BPP 1970 [1843]:101). In the interim, the family made its home in the hollow of a large gum tree (Santich 1998:94). Yields varied, as the crop of wheat sown in June was large, reportedly 40 bushels per acre, while that sown in July was poor, and potatoes planted in July and August failed (BPP 1970 [1843]:101).

Early agricultural production in the Willunga region focused on cereals, primarily wheat (Triticum aestivum), barley (Hordeum distichon), rye (Secale cereale) and oats (Avena sativa). Yields were initially good and returns high (Hallack 1892:1). Over the next 20 years, cereal production steadily increased such that surpluses were produced for export from the region. However, continuous wheat cropping rapidly exhausted soil nutrients, which already had low concentrations of phosphorus and nitrogen (Northcote 1976:65). Harvest yields reduced dramatically and sparked an exodus of farmers to seek new pastures (Hallack 1892:1; Whitelock 1985:260; Linn 1991:85). Wheat cultivation decreased rapidly from 1865 to 1889, leading to the closure of flour mills, while coastal jetties became 'tombstones to a departed industry' (Hallack 1892:1). By 1938-39, there were no wheat sales for the region (Charlick 1939), although other fodder and cereal crops remained important: initially hay and then barley from the 1940s being predominant.

Those farmers who remained in Willunga focused on the production of clover (Trifolium spp.) and lucerne (Medicago sativa) for hay, and oats for sheep and cattle feed, and diversified into fruit and market gardening for local and Adelaide markets (Santich 1998:53). Horticulture was well-established in other colonies by this time, and settlers used their experiences and acquired skills to yield good crops of fruits and vegetables in often unfamiliar environments.

The diversity of fruit production that followed the demise of cereals was on display at the Willunga show in 1883: 'apples, pears, quinces, peaches, damsons, grapes and mulberries, together with dried apricots, peaches, currants and raisins, preserved figs and softshell almonds' (Santich 1998:53). Although olives (Olea europaea) were brought to South Australia with the first arrivals on the Buffalo in 1836, they were not extensively planted until the mid 20th century (Santich 1998:59), with a marked increase since 2003.

The most significant arboricultural crop associated with the Willunga region was almond (Prunus amygdalus). Initially, trees were planted in mixed orchards and small lots, but the size of plantings increased following the development of new varieties. From the early 19th century production increased to meet increasing demand, such that by the 1970s more than half of Australia's almonds were grown there (Santich 1998:58). During the 1990s, the profit potential of wine grapes lured many growers to remove almond trees and other orchards and replace them with vines; the focus of the almond industry has now shifted to the Riverland region of South Australia.

John Reynell established the first South Australian vineyard in 1838 at Reynella on the Noarlunga Plains north of Willunga (Richardson 1936:63). Wine production did not emerge as a significant economic activity until the second half of the 20th century. Since 1980, vines have become the dominant economic crop plant on the Willunga Plains, even though some vineyards in the south have recently given way to olive groves.

In summary, 19th century colonists in South Australia deliberately sought to transpose European land management systems on to the landscape (Hobbs and Hopkins 1990:93; see Williams 1974). The inappropriateness of European crops and farming technology to the Willunga Plains has led, in part, to successive transformations in agricultural practices. As for other parts of the continent, the adjustment of European land-use practices to the Australian environment, or process of landscape learning (see Rockman 2003), has been slow, has been partially imposed through necessity, and is still ongoing. 


\section{California Road Wetland}

The California Road Wetland is relatively large for the area, permanent and located in the Ingleburn Creek catchment, also known as Maslin's Creek (Figure 1 lower). The site is an open wetland adjacent to a permanently wet and periodically flowing creek. The creek and wetland have been dissected by roadways which, despite the installation of under-road drains, have affected and impeded drainage. Topography is gentle, with low gradient slopes along the edge of the creek and wetland. Sediments and microfossils accumulating in the wetland comprise in situ biogenic, as well as detrital colluvial and fluvial, components.

During McLaren's survey of 1840, the surveyor noted a wetland in this locale, with stands of woolly ti-tree (Leptospermum lanigerum), which are still common today with surrounding bulrush (Typha domingensis) and common reed (Phragmites australis). This shrubland assemblage was characteristic of wetlands on the Willunga Plains at that time, with the California Road Wetland being one of the few places where it has survived today. In and around the wetland are other indigenous plants, such as native water parsley (Berula erecta), exotic weeds, such as salvation jane (Echium plantagineum), and cultivar escapees, including bearded oat (Avena barbata) and olive (Olea europaea). Slopes adjacent to the wetland are currently cultivated with vines (Vitis sp.).

\section{Field methods}

Two $1 \mathrm{~m}$ sediment long cores were extracted in the field using a D-section corer. These cores were subsequently stored under refrigeration at the Department of Geographical and Environmental Studies, University of Adelaide. Only Core 1 was subsampled for multiple types of dating, palaeoenvironmental and sedimentological analyses. Subsamples of ca. $1 \mathrm{~g}$ (dry weight) were collected at ca. $5 \mathrm{~cm}$ intervals for matched, or paired, microfossil analyses. Analyses were undertaken following standard procedures for diatoms (Battarbee 1986), phytoliths (Powers et al. 1989; Parr 2002), pollen (Faegri and Iversen 1989) and microcharcoal (Clark 1982). Moisture content and loss on ignition (LOI) measurements were undertaken on $1 \mathrm{~cm}$ thick subsamples collected every $2 \mathrm{~cm}$ down the core except at 48-49 $\mathrm{cm}$ (Rowell 1994); however, the cores were inadvertently thrown away before detailed stratigraphic descriptions could be completed. Three bulk sediment subsamples were submitted to the Australian Nuclear Science and Technology Organisation (ANSTO) to assess the sediments for ${ }^{210} \mathrm{~Pb}$ (lead) and ${ }^{137} \mathrm{Cs}$ (caesium) dating. Additionally, samples were processed to obtain a fine fraction for AMS dating from basal sediments, but insufficient carbon was present (Beta Analytic pers comm. 2007).

\section{Multi-proxy results: General trends and diagnostics}

\section{Sedimentary description}

Distinct differences in water content and loss on ignition (LOI) occurred down the sedimentary sequence (Figure 2). Organic rich, fibrous, peaty matrices characterised all but one of the upper few samples. Most samples in the field appeared to be organic rich, fibrous, peaty matrices; however, samples had highly variable water contents and LOI suggested generally high, although variable in the upper $10 \mathrm{~cm}$, mineral contents. Mineral inputs were predominantly terrestrial, silt and sand-sized particles. Only the light-coloured sands at the base of the core, below approximately $80 \mathrm{cmbs}$ ( $\mathrm{cm}$ below surface), appeared of significantly different character in the field. 


\section{Distribution and abundance of microfossils}

The multi-proxy summary diagram (Figure 3) shows marked differences between the distributions and abundance of pollen, phytoliths and diatoms in the sedimentary sequence. Phytoliths were abundant in all residue samples, with the exception of the four lowermost samples and sample 7. In contrast, most samples had poor pollen preservation, with pollen abundance decreasing down the sequence. Preservation was extremely poor in the lower half of the sequence and pollen was absent in sample 13 and the three lowermost samples 19,20 and 21. Similarly, diatoms were absent in much of the lower sequence; they occurred intermittently in samples 16 to 5, above which there was a marked increase in abundance and good preservation of unbroken diatoms.

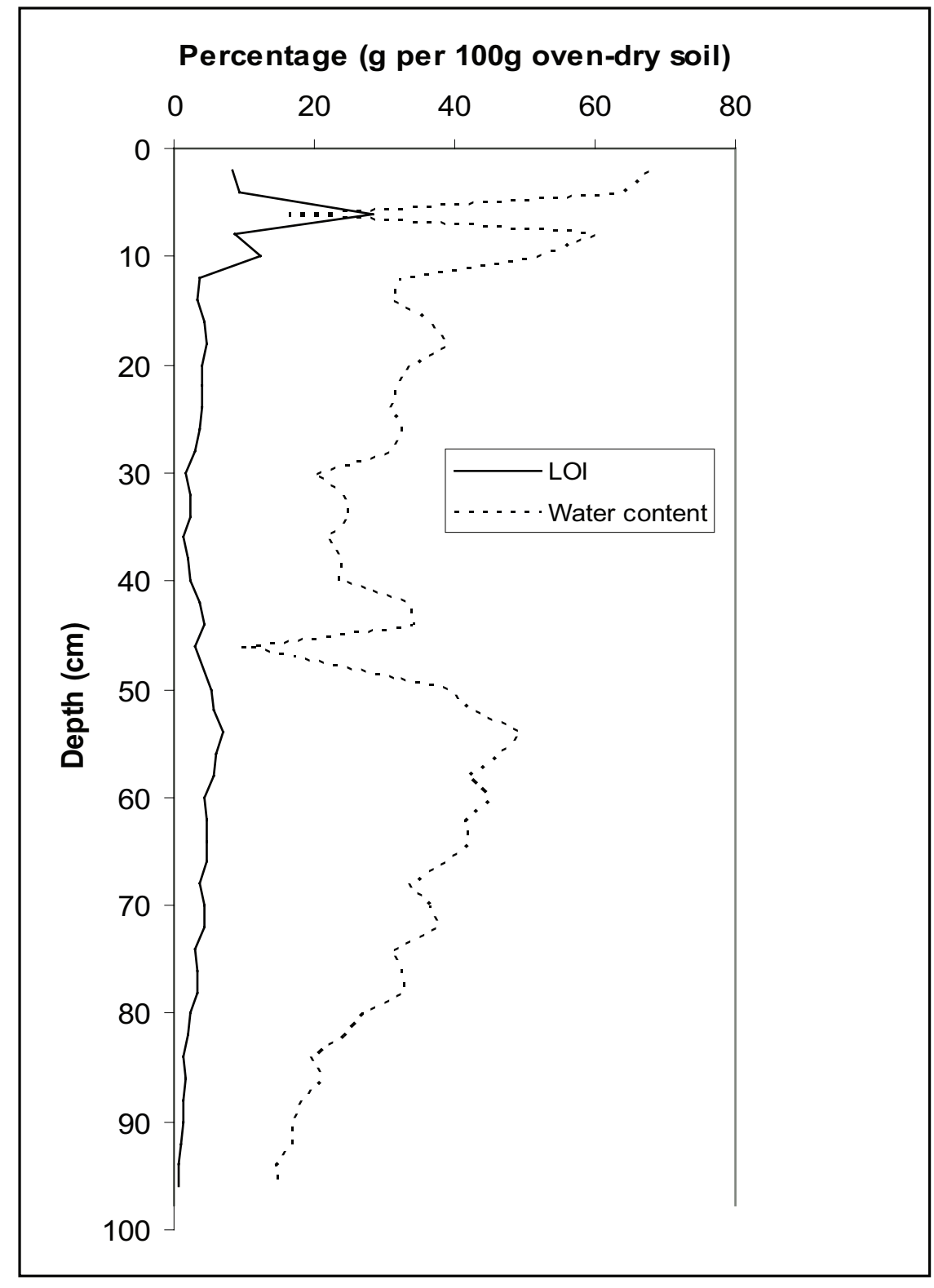

Figure 2. Water content and loss on ignition (LOI) data for subsamples from core 1. California Road Wetland (following methods in Rowell 1994:48).

Pollen

Most samples collected had extremely poor pollen preservation, with pollen abundance decreasing down the core (Table 1; Figure 3). The majority contained too few grains to make analysis meaningful. Wetland species - i.e. derived from on-site vegetation - predominated, with 


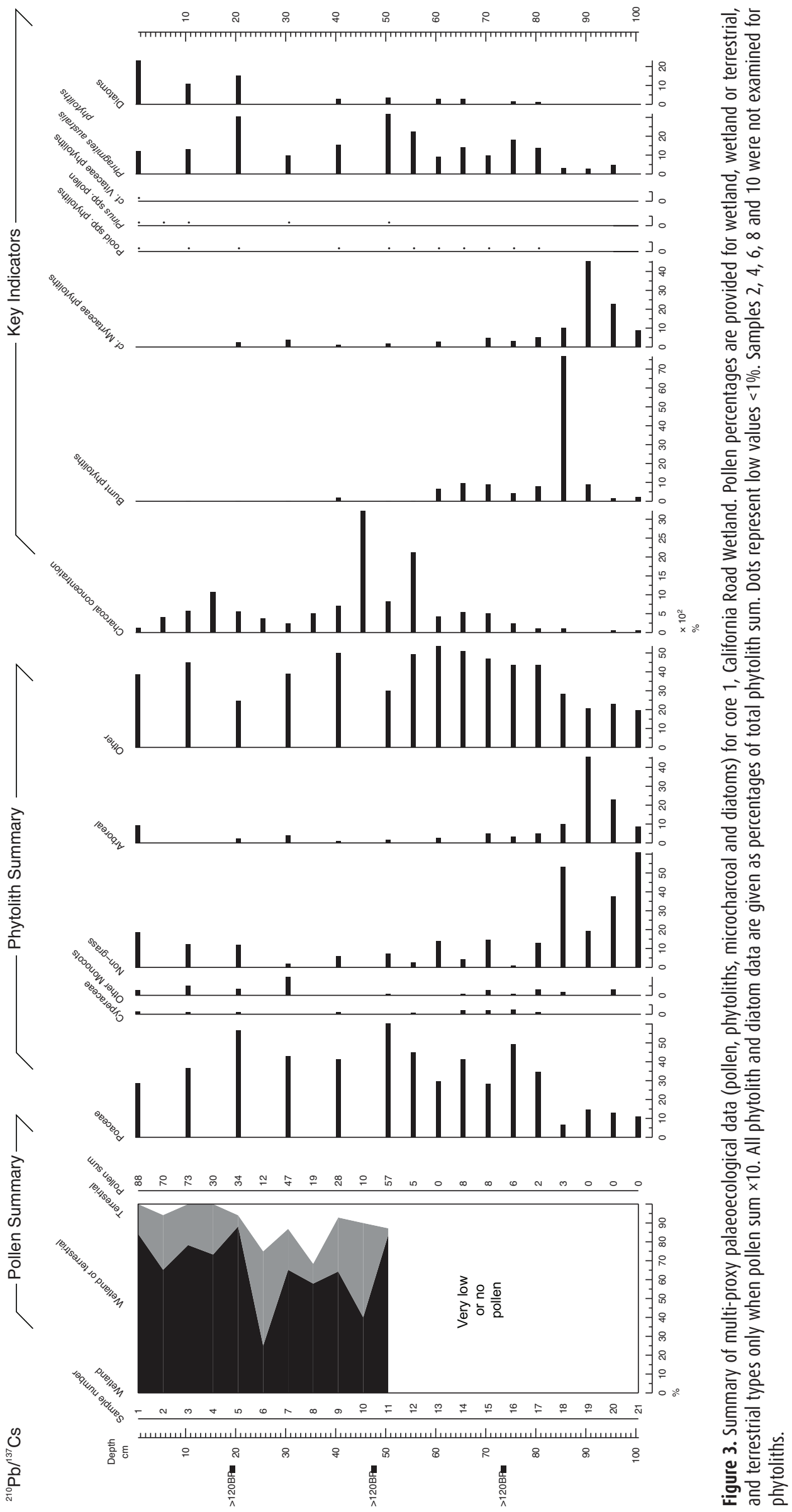


few off-site terrestrial species present. Although low pollen frequencies occurred throughout the core and hinder interpretation, some highly tentative observations are possible largely based on presence/absence.

The assemblage is dominated by Cyperaceae and Halogoraceae from sample 17 upwards, and indicates on-site vegetation growing in the wetland. Leptospermum pollen only occurs in samples 1,2 and 5 (Table 1). By contrast, the terrestrial component has much lower representation throughout and especially in the upper five samples, where frequencies were recorded as being absent or very low. Moderate terrestrial pollen frequencies occur in samples 6 to 11. Asteraceae pollen is present from sample 10 to the top, and absent in samples below. Poaceae pollen is present in the upper part of the sequence (from sample 6). Most notably, arboreal species are low throughout. Single Eucalyptus-type grains representing Myrtaceae occur in only two samples (8 and 11); Banksia marginata is very rare and was recorded in the middle of the sequence (samples 7, 8,11 and 15); and Allocasuarina verticellata occurs sporadically throughout

Table 1. Summary of pollen grains and fern spore counts for core 1, California Road Wetland.

\begin{tabular}{|c|c|c|c|c|c|c|c|c|c|c|c|c|c|c|c|c|c|c|c|c|c|}
\hline \multirow{2}{*}{ Pollen/Spore type } & \multicolumn{21}{|c|}{ Sample } \\
\hline & 1 & 2 & 3 & 4 & 5 & 6 & 7 & 8 & 9 & 10 & 11 & 12 & 13 & 14 & 15 & 16 & 17 & 18 & 19 & 20 & 21 \\
\hline \multicolumn{22}{|l|}{ Wetland } \\
\hline Cyperaceae - Baumea type & 56 & 25 & 22 & 9 & 16 & 3 & 17 & 8 & 3 & 1 & 19 & 1 & & 2 & 2 & 1 & 2 & & & & \\
\hline Cyperaceae - Scirpus type & 9 & 14 & 18 & 11 & 6 & & 11 & & 13 & & 19 & 2 & & 3 & & & & & & & \\
\hline Restionaceae & & 1 & & & & & & & & & & & & & & & & & & & \\
\hline $\begin{array}{l}\text { Halogoraceae (Myriophyllum/ } \\
\text { Gonocarpus) }\end{array}$ & 1 & & 13 & 2 & 5 & & 1 & & & 1 & 6 & & & 1 & & & & & & & \\
\hline Monolete fern spore & & & 1 & & & & & 2 & & & & & & & & 1 & & & & & \\
\hline Trilete fern spore & & & & & 1 & & & 1 & 2 & 1 & 2 & 1 & & & & 1 & & 1 & & & \\
\hline Goodenia & & 1 & & & & & & & & & & & & & & & & & & & \\
\hline Geraniaceae & & & & & & & 1 & & & 1 & & & & & & & & & & & \\
\hline Leptospermum & 4 & 4 & & & 2 & & & & & & & & & & & & & & & & \\
\hline \multicolumn{22}{|l|}{ Wetland or Terrestrial } \\
\hline Asteraceae - Tubuliflorae & 2 & 5 & 4 & 2 & 1 & 1 & 2 & 2 & 4 & 2 & & & & & & & & & & & \\
\hline Asteraceae - Liguliflorae & 6 & 8 & 2 & 6 & & 3 & 8 & & 4 & 3 & & & & & & & & & & & \\
\hline Poaceae > 50 um & 2 & 1 & 6 & & & & & & & & 2 & & & & & & & & & & \\
\hline Poaceae < 50 um & 3 & 6 & 3 & & 1 & 2 & & & & & & & & & & & & & & & \\
\hline \multicolumn{22}{|l|}{ Terrestrial } \\
\hline Myrtacaeae - Eucalyptus type & & & & & & 2 & & 1 & & & 1 & & & & & & & & & & \\
\hline Banksia marginato & & & & & & & 1 & 2 & & & 2 & & & & 1 & & & & & & \\
\hline Allocasuarina (prob verticillata) & & 2 & & & 2 & 1 & 3 & 3 & 1 & & 1 & 1 & & 2 & 5 & 3 & & 2 & & & \\
\hline $3 C$ prolate $30 \mu m$ & & & & & & & 1 & & & & 3 & & & & & & & & & & \\
\hline Chenopodiaceae & & & & & & & 1 & & & 1 & & & & & & & & & & & \\
\hline Dodonaea & & 2 & & & & & & & 1 & & & & & & & & & & & & \\
\hline Pinus & 5 & 1 & 4 & & & & 1 & & & & 2 & & & & & & & & & & \\
\hline Total grains & 88 & 70 & 73 & 30 & 34 & 12 & 47 & 19 & 28 & 10 & 57 & 5 & 0 & 8 & 8 & 6 & 2 & 3 & 0 & 0 & 0 \\
\hline
\end{tabular}

the middle to lower parts of the sequence (samples 5 to 18) and is absent from all but one of the five uppermost samples.

The European-introduced Pinus spp. pollen appears for the first time in sample 11, concomitant with the first major increase in pollen abundance, and it is present sporadically throughout the upper sequence. Pinus pollen can be used as a chronological marker, albeit regionally specific, of colonial settlement across Australia (Behre 1986). Pine plantations were not established in the region until the 1930s, which may be reflected in the continuous 
presence of Pinus pollen from sample 3 upwards, with earlier records reflecting planting for ornamentation and landscaping. Given the nature of pollen preservation in samples throughout the core, the absence of Pinus pollen in lower samples might not reliably indicate an absence of this introduced genus.

\section{Phytoliths}

In contrast to diatoms and pollen, phytoliths were abundant and well preserved in all samples, with the exception of sample 7 and the basal samples 18 to 21, where they were less abundant but still in sufficient frequencies to enable meaningful interpretations of vegetation change for the wetland and its vicinity (Figure 4). Phytolith reference collections for Australian vegetation are currently limited, hindering taxonomic identifications (Clifford and Watson 1977; Hart 1992; Lentfer et al. 1997; Bowdery 1998; Wallis 2000, 2001). Additional reference material was obtained from a number of common plant species currently growing at the California Road Wetland (Table 2); the dry-ashing and self-draining crucible procedure (Lentfer 2006) was used for phytolith extraction from these plant samples. Seventy-six phytolith morphotypes were distinguished from the core samples; diagnostic types were assigned to plant species or groups, and non-diagnostic types were assigned to three general categories: elongates, polyhedrals and stomates.

The phytolith record shows that the lowermost samples, 18 to 21, have a predominance of non-grass and arboreal morphotypes mainly characterised by psilate globular morphotypes, found commonly in Myrtaceae, including Leptospermum and Eucalyptus spp. (compare Figures $5 \mathrm{E}$ and $5 \mathrm{~F}$ ) and other globular morphotypes with nodulose and verrucate surface textures. Grasses, including the arundinoid species Phragmites australis (compare Figures 5A and 5B) and possibly Danthonia, are present, but compared with the overall sequence, have relatively low frequencies in the basal samples.

There is a distinct and sudden decline in arboreal morphotypes and a marked increase in grass morphotypes directly above sample 18. Morphotypes from Phragmites australis become the most prevalent from sample 17 and upwards, persisting throughout the entire sequence. The absence of Phragmites australis pollen in these same samples reflects its under-representation, as

Table 2. Phytolith production in some of the most common plants at the California Road Wetland site.

\begin{tabular}{l|c|}
\hline Species & Phytolith production \\
\hline Leptospermum lanigerum & + \\
\hline Typha domingensis & - \\
Carex divisa & + \\
\hline Gahnia trifida & + \\
\hline Phragmites australis & + \\
\hline Avena barbato & + \\
\hline Bromus catharticus & - \\
\hline Samolus repens & + \\
\hline Schoenoplectus pungens & + \\
\hline Cynara cardunculus & + \\
\hline Rosa canina & + \\
\hline Vitis sp. & + \\
\hline Berula erecto & + \\
\hline
\end{tabular}




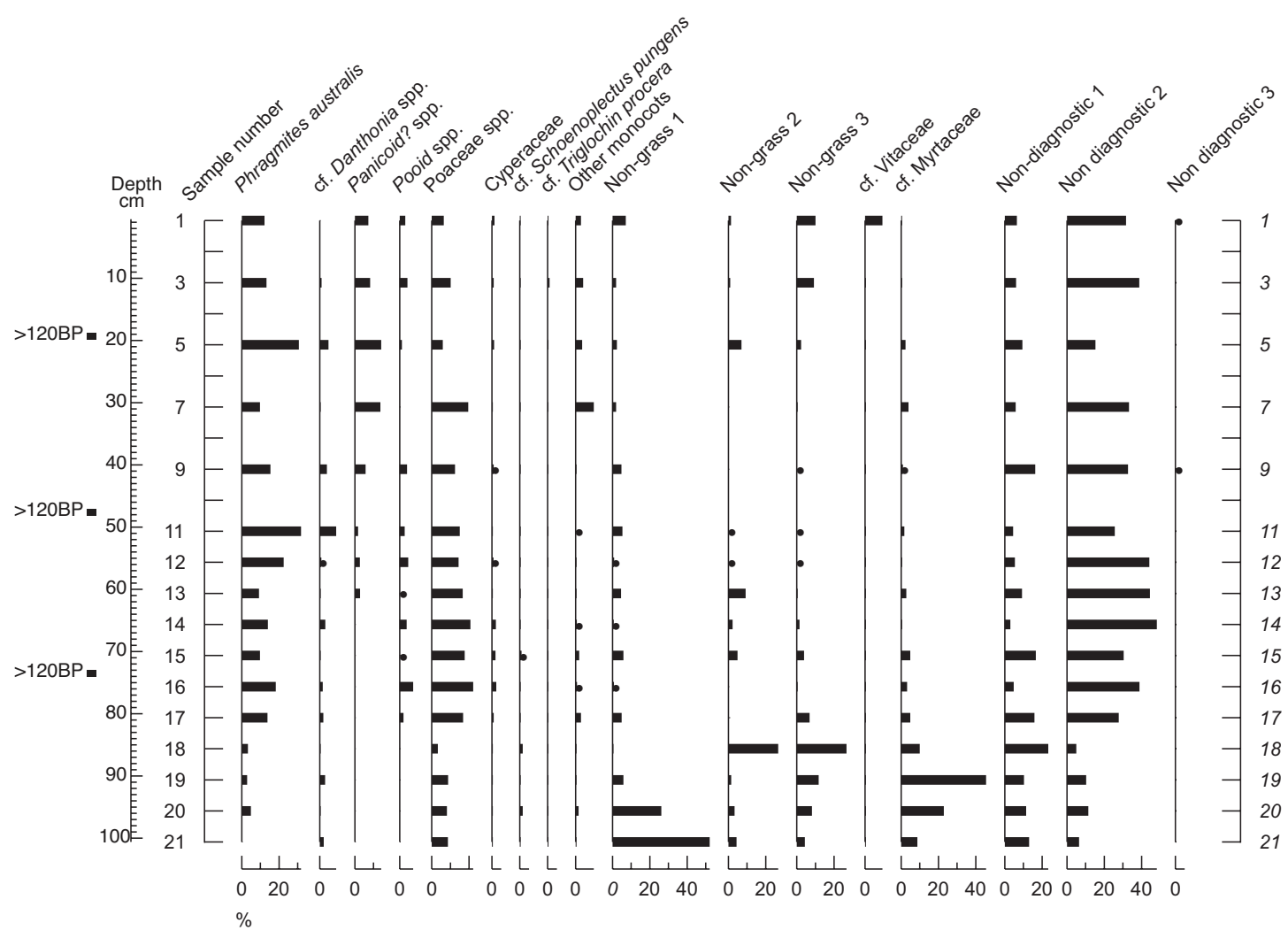

Figure 4. Distribution of phytolith morphotypes in the sedimentary sequence for core 1, California Road Wetland. Percentage values $<1$ are represented by $\bullet$.

well as that of Typha spp., in pollen spectra generally (Finkelstein and Davis 2005).

Morphotypes typical of pooid grasses including the cereal crops (Triticum, Hordeum and Avena species), related weeds (e.g., Avena barbata) and the introduced grass Bromus catharticus (Lentfer et al. 1997) appear in the assemblage for the first time in sample 17 and persist throughout the rest of the sequence (Figures $5 \mathrm{G}$ and $5 \mathrm{H}$ ). Larger Poaceae pollen grain types are present from sample 5 upwards, potentially indicative of exotic grasses, and absent from lower contexts due to poor pollen preservation generally. Bilobate morphotypes typical of panicoid grasses, but also present in arundinoid and chloridoid grasses, appear later in the sequence at sample 14, and Cyperaceae morphotypes characteristic of Ghania and Carex first appear in sample 16 at the same level as the first appearance of diatoms. Finally, morphotypes typical of the grape family Vitaceae (compare Figures 5C and 5D) occur only in the uppermost sample.

\section{Distribution and abundance of microcharcoal and burnt phytoliths}

There is a distinct disparity between the distributions and abundance of microcharcoal and burnt phytoliths. Burnt phytoliths, identified from a black, opaque appearance under transmitted light (Lentfer and Torrence 2007; see Figure 6), were recorded in the lower part of the sequence. Most notably, a major peak occurred in sample 18, concomitant with a major decline in Myrtaceae phytoliths. In contrast, microcharcoal was more common in the upper part of the sequence, with lesser and major peaks occurring in samples 12 and 10, respectively.

\section{Dating}

The assessment of samples for ${ }^{210} \mathrm{~Pb}$ (lead) and ${ }^{137} \mathrm{Cs}$ (caesium) dating suggests that either 


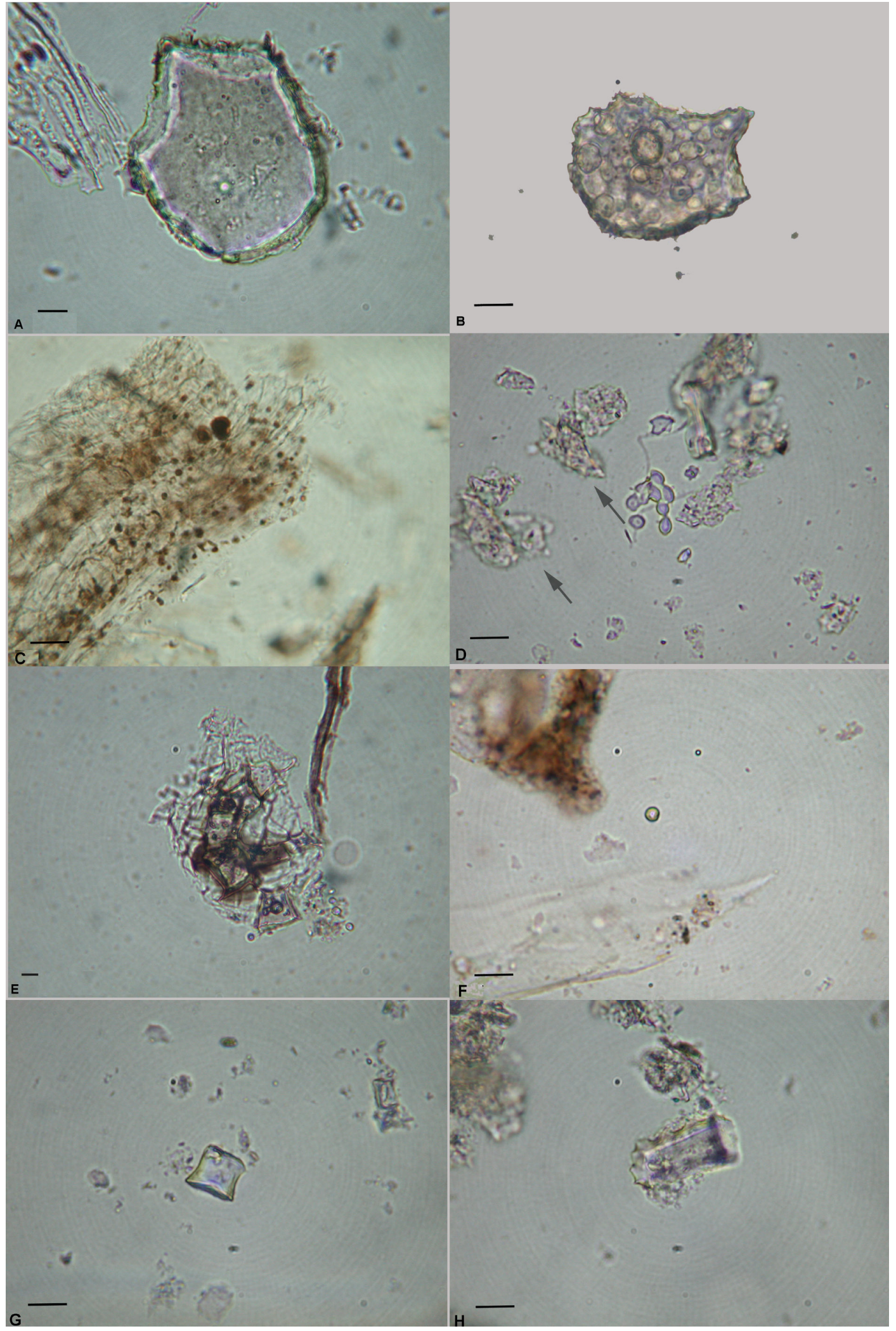

Figure 5. Photomicrographs comparing diagnostic phytoliths from plant reference material and California Road Wetland sediments. Example of large cuneiform (bulliform) phytoliths from Phragmites australis (A) and weathered cuneiform phytolith extracted from sediment sample 20 (B). Silicified epidermis from cultivated grape vine leaves (C) and microfossils found in sediment sample 1 (D). Psilate globular phytoliths from Eucalyptus sp. (E) and sediment sample 19 (F). Examples of silica bodies (epidermal short cells) typical of pooid grasses, including the cereal crops. Both (G) (sample 9) and (H) (sample 11) were recovered from California Road Wetland sediments above sample 18 and occur in wheat (Triticum spp.) (see Lentfer et al. 1997; Ball et al. 1993, 1999). The scale bar in all panels represents $10 \mu \mathrm{m}$. 
all three samples chosen were older than the timeframes ordinarily dated by these techniques, or the samples had been diluted with older sediments eroded from the catchment (Jennifer Harrison pers comm. 2005). If taken at face value, this would suggest that all three samples, which were taken above samples 5,11 and 16 (see Figure 3), were older than at least 120 years. However, the deposition of 'old' sediments in the wetland may have contributed to the greater-than-120-year ages (see Gale et al. 1995 for a detailed examination of this problem). Given uncertainties in the interpretation of the lead and caesium assessments, as well as the

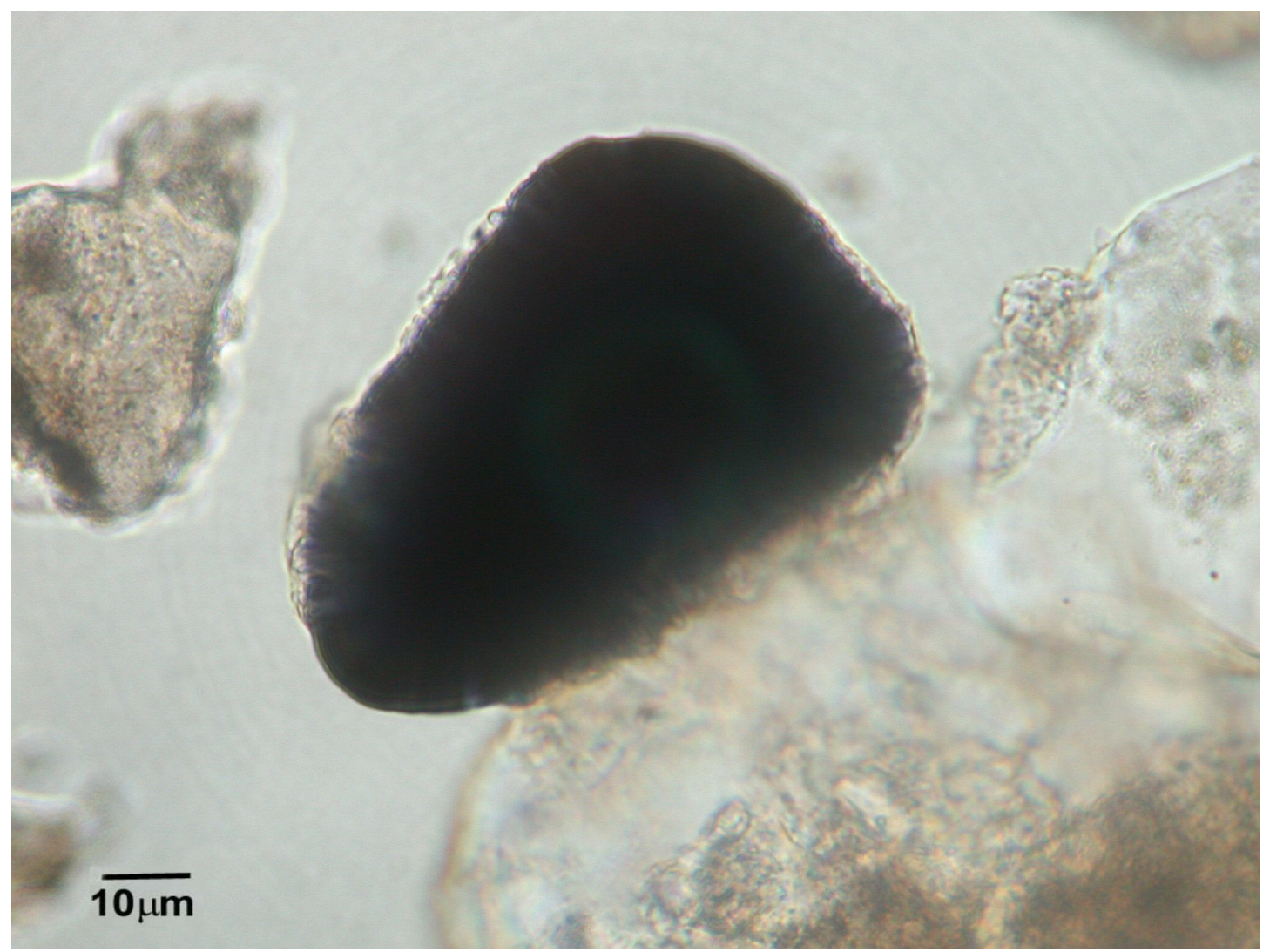

Figure 6. Photomicrograph of a large burnt cuneiform phytolith extracted from sample 14.

inability to obtain a sufficient sample for AMS dating from the basal sediment, relative dating of the stratigraphy has been undertaken using diagnostic pollen and phytolith types. The use of biostratigraphic markers will support an interpretation that all the sediments from directly above sample 5 to the base of the core are at least 120 years old, i.e. pre-date ca. 1880 .

\section{Dating, diagnostics and resolution}

In the absence of a suitable chronometric method, diagnostic pollen and phytoliths have been relied on to provide approximate and relative indicators of age. Pinus pollen, cereal phytoliths and grape phytoliths can be interpreted with respect to a land-use history of the vicinity to provide relative and reasonably reliable chronological markers; they appear reliable because they first occur in the correct chronostratigraphic order as inferred from the land-use history (see Figure 3). Land-use histories for the California Road Wetland vicinity suggest woodland clearance and mixed farming, including cereals, occurred in the 1840s, with cereals persisting into the 20th century. Viticulture did not occur in this area of the Willunga Plains until the late 20th century.

Based on the distribution of pollen, phytoliths and microcharcoal, the majority of the 
sediment accumulated rapidly in the 19th century. Cereal phytoliths first occur in sample 17, following a major burnt phytolith peak and shift in vegetation, interpreted to represent land clearance in the early 1840s (see below). Sample 11 contains the earliest occurrence of Pinus pollen, and grape phytoliths occur in only the uppermost sample (sample 1), which is anticipated given that it is primarily a late-20th century crop in this area. To compare, the ${ }^{210} \mathrm{~Pb}$ dating assessment suggests sample 5 dates to at least the 1880 s, although it may be more recent if diluted with old sediment. Taking all the chronological markers together, samples 17 to 5 (or above) may represent fewer than 40 years; rapid deposition may account for the rarity of diatoms below sample 5. Thus, the upper four samples (or fewer) represent at least the past 120 years. Consequently, the majority of the stratigraphy probably represents rapid deposition following initial clearance in the mid 19th century.

Other sites in Australia witness similar depositional trends, as well as problematic ${ }^{210} \mathrm{~Pb}$ dating and pollen preservation, with rapid sedimentation following initial European colonisation (Gale et al. 1995; Haworth et al. 1999). For example, Gale et al. (1995) show extremely high sedimentation rates during the first decade or two of European settlement for a lake in the New England Tablelands of eastern New South Wales; these are inferred to result from land clearance for pastoralism. At California Road Wetland, rapid sedimentation followed land clearance for mixed farming and very low sedimentation has occurred for the past 120 years. The effects of such rapid erosion on often fragile and ancient soils must have been severe, and might have contributed to the nutrient deficiencies of soils in the Willunga Basin.

Thus, the majority of the core appears to fall into a problematic period; sediments below $20 \mathrm{cmbs}$ seem to be older than the minimum reliability of ${ }^{210} \mathrm{~Pb}$ dating in alluvial and colluvial settings, namely ca. 120 years (after Gale et al. 1995), and sediments above at least $80 \mathrm{cmbs}$ contain pollen or phytoliths of exotic species, post-date 1840 and are too young to date with any precision using radiocarbon dating (whether AMS or conventional). Analysis of the California Road Wetland core using diagnostic pollen and phytoliths as chronological markers provides a reasonable, but relatively low resolution, solution to resolving dating problems at this site to clearly show the dramatic transformation of the landscape during the first 40 years or so of European colonisation.

\section{Comparing historical and palaeoecological records}

The results of the multi-proxy palaeoenvironmental analysis are indicative of marked changes in vegetation at the California Road Wetland site as a result of European settlement. The distribution of phytoliths shows that the vegetation represented in the lowermost levels was characterised by myrtaceous woody shrubs and trees with little grass ground cover. This type of vegetation cover seems to indicate a more closed woodland locally, perhaps in the proximity of creek-line vegetation, as opposed to the open woodland that is ordinarily considered to have existed on the Willunga Plains before European settlement.

Directly following a major burning event, represented by burnt phytoliths in sample 18, there was a rapid decline in arboreal vegetation and an increased predominance of grasses, dominated by the locally growing common reed Phragmites australis, perhaps indicating eutrophic conditions locally. The pollen analysis corroborates the phytolith evidence by showing a predominance of wetland sedge and Halogoraceae species in the middle-to-upper sequence above sample 18. Successive European influences are signalled by the presence of pooid grass phytoliths, Pinus spp. pollen, and grape phytoliths.

Pooid grass phytoliths appear for the first time in sample 17, immediately after the first major burning event, and most likely represent introduced cereals - wheat, barley and oats, 
closely related introduced weeds such as the bearded oat Avena barbata, and introduced forage grasses. Unfortunately, inflorescence phytoliths that would have enabled more precise identifications of specific cereal crops and grasses (Lentfer et al. 1997; Ball et al. 1999) were not observed in the phytolith assemblages. In contrast with the poorly preserved palynological record, pollen grains identified as potentially cereal occur first in sample 11 . The presence of these pooid grasses accords with the introduction of mixed farming by the first European settlers in the early 1840 s.

Pinus pollen occurs in the middle of the sequence (from sample 11), concomitant with the first good preservation of pollen. The possibility that Pinus was present earlier but its pollen was not preserved in the sequence is not discounted. Like the introduced pooid grass phytoliths, Pinus pollen in this part of South Australia is indicative of settlement during the 19th century. The presence of grape phytoliths in the uppermost sample represents the recent transformation of this area to viticulture. The absence of almond pollen is not necessarily surprising, given poor pollen preservation in most samples, and because, according to historical records, almonds have not been significant on adjacent slopes.

The appearance of introduced species, the peak in burnt phytoliths and the transformation of arboreal vegetation to an open landscape are signatures of intentional clearance of bushland vegetation for farming. Historic records indicate initial clearances for farming in this part of the Willunga Plains occurred in the 1840s. Sample 18 marks the 'apocalyptic' transformation of an open woodland landscape to a farmed landscape.

\section{Fire histories}

Flammability has been a feature of the Australian landscape since before human colonisation of the continent (e.g. Bradstock et al. 2001), and burning was characteristic of Aboriginal land management practices, whether to increase foraging opportunities (Jones 1969; Gott 2005) or to increase game and facilitate hunting (Bowman et al. 2001). Given the associations of the burnt phytolith peak with the transformation of an arboreal landscape to an open landscape and with European-introduced exotics, it is taken to be more representative of land clearance associated with initial colonisation of the area in the 1840s than the microcharcoal record. European settlement and clearances in the region entailed clear-felling and the burning of unused vegetation material, with subsequent ploughing.

The burnt phytolith and microcharcoal records reflect varying proxy levels of burning down the sequence, with clear, but asynchronous peaks. The disparity between the two microfossil records is intriguing and two sets of processes can be proffered to account for the observed phenomena. Firstly, the source areas for both phytoliths and microcharcoal are predominantly the same, namely the swamp (in situ), adjacent slopes (colluvial) and the catchment (fluvial). Asynchronous microfossil peaks could plausibly represent differential depositional pathways from local and extralocal sources, perhaps with the phytolith assemblage being anticipated to exhibit a greater local component than microcharcoal.

Secondly, the disparity could indicate distinct fire regimes at different times, most likely associated with changing vegetation and land uses. The burnt phytolith peak may derive from the more intense fires associated with the clearance and burning of myrtaceous woodland, whereas burnt phytoliths are largely absent from the less intense fires occurring in the more open, post-1840 farmed landscape. As to why microcharcoal is absent from the earlier burning event, but more frequent in later, less intense fires, this is uncertain, although it has been noted that 'carbonised particles are particularly well preserved when cool fires burn in grass and sedgelands; fires in forests tend to be more complete in reducing fuel to ash which can leach and wash away' (Gillieson et al. 1989:111). 
At present, there is insufficient data on the comparable taphonomies of microcharcoal and burnt phytoliths to interpret what the asynchronies between the two records represent. However, the asynchronous distribution of burnt phytoliths and microcharcoal raises a significant and unresolved methodological issue for the interpretation of fire histories in the Australian landscape. As with previous debates about the relative merits of macrocharcoal (not analysed during this study) and microcharcoal as an indicator of fire regimes (see Whitlock and Larson 2001), the relative worth of burnt phytoliths for the reconstruction of fire histories needs to be more fully explored.

\section{Conclusions}

A multi-proxy record indicates the degree of ecological transformation associated with European colonisation of the Willunga Plains during the second half of the 19th century. European colonisation during the 1840s was 'apocalyptic' in terms of vegetation changes and, presumably, for associated soils (although not investigated in detail here); open woodland was rapidly transformed into an open, farmed landscape. Unfortunately, dating problems have enabled only a relatively coarse-grained interpretation of palaeoecological transformation to be reconstructed, a relatively common problem at sites in Australia for the period of early European settlement.

Although of only limited chronological resolution, the study has methodological value. The study reaffirms the value of integrating historical research with multi-proxy palaeoecology in order to understand landscape change in Australia. The use of both approaches provides complementary and mutually corroborating data sets that, on the one hand, enable some scientific measure of historically documented events and, on the other hand, refine and enliven interpretations of palaeoecological signals. Too often, historical background studies are a cursory appendage to palaeoecological research. In this case, the history enables calibration of the relative chronology derived from microfossils. However, history alone does not usually provide a reliable measure of the scale of environmental impacts, which were effectively catastrophic for the ecology of this area in the mid 19th century. This type of study serves as an experimental analogue for places and time periods for which historical records are limited or absent.

Most significantly, the study demonstrates the value of multi-proxy investigations using paired phytolith and pollen analyses in the Australian context. As demonstrated in studies across the world (e.g. Piperno et al. 1991; Denham et al. 2003), but an approach previously not undertaken in Australia, paired phytolith and pollen analyses provide a more robust reconstruction of vegetation and land-use changes in the past than using one method alone. At the California Road Wetland site, and despite limited phytolith reference collections for South Australian flora, phytoliths have proven especially significant because of poor pollen preservation. This study demonstrates the enormous potential of phytolith research to shed light on past human-environment interactions in Australia over the short term (timescales of the past 500 years), as well as its well-documented capacity to shed light on the long term (timescales of millennia and tens of millennia; Bowdery 1998; Wallis 2000).

Multi-proxy (pollen and phytolith) diagnostics are significant for overcoming a 'chronological gap' between the older limits of $210 \mathrm{~Pb}$ dating and the younger limits and precision of radiocarbon dating. The identification of multiple diagnostic pollen and phytoliths derived from exotics has provided chronological guides - taken together with general palaeoecological trends, fire histories and the historical records - for initial land clearance and mixed farming (pooid cereal-type phytoliths), the early period of European settlement (Pinus pollen), and recent viticulture (Vitaceae phytoliths). 


\section{Acknowledgements}

Denham directed the palaeoecological project and obtained funding from a Flinders University research grant (with Pam Smith) and from the Australian Research Councilfunded Adelaide Hills Face Zone project (courtesy of Pam Smith and Donald Pate). Fieldwork was undertaken in 2004 by Barr, Bickford, Denham and Stuart. Microfossil analyses were conducted by Barr (diatoms), Bickford (pollen and microcharcoal) and Lentfer (phytoliths). Stuart undertook a historical archaeology, focused on agricultural history, of the Willunga Basin, as well as the sedimentological analyses. The authors thank Jennifer Harrison (radioanalyst, ANSTO) for undertaking the ${ }^{210} \mathrm{~Pb}$ (lead) and ${ }^{137} \mathrm{Cs}$ (caesium) dating; Keryn Walshe (South Australian Museum) for information on the archaeology of the Willunga Plains; Kale Sniderman for preparation of pollen slides, and, with Phil Scamp and Kara Valle (SGES, Monash), for preparation of the figures; John Dodson, Simon Haberle and Scott Mooney for constructive criticism of an earlier draft of this paper; and anonymous reviewers for comments on the final draft.

\section{References}

Adamson, D.A. and Fox, M.D. 1982. Change in Australasian vegetation since European settlement. In: Smith, J.M.B. (ed), A History of Australasian Vegetation, pp. 109-146. Sydney: McGraw-Hill.

Ball, T.B., Brotherson, J.D. and Gardner, J.S. 1993. A typologic and morphometric study of variation in phytoliths from einkorn wheat (Triticum monococcum). Canadian Journal of Botany 71:1182-1192.

Ball, T.B., Gardner, J.S. and Anderson, N. 1999. Identifying inflorescence phytoliths from selected species of wheat (Triticum monococcum, T. dicoccon, T. dococcoides, and T. aestivum) and barley (Hordeum vulgare and H. spontaneum). American Journal of Botany 86:16151623.

Battarbee, R.W. 1986. Diatom analysis. In: Berglund, B.E. (ed), Handbook of Holocene Palaeoecology and Palaeohydrology. Chichester: John Wiley and Sons.

Behre, K.E. 1986. Anthropogenic Indicators in Pollen Diagrams. Rotterdam: A.A. Balkema.

Bickford, S.A. 2001. A historical perspective on recent landscape transformation: integrating palaeoecological, documentary and contemporary evidence for former vegetation patterns and dynamics in the Fleurieu Peninsula, South Australia. Unpublished $\mathrm{PhD}$ thesis, University of Adelaide.

Bickford, S. and Gell, P. 2005. Holocene vegetation change, Aboriginal wetland use and the impact of European settlement on the Fleurieu Peninsula, South Australia. The Holocene 15:200-215.

Bickford, S., Gell, P. and Hancock, G.J. 2008. Wetland and terrestrial vegetation change since European settlement on the Fleurieu Peninsula, South Australia. The Holocene 18:425-36.

Bowdery, D. 1998. Phytolith Analysis Applied to Pleistocene-Holocene Archaeological Sites in the Australian Arid Zone. BAR International Monograph Series 695. Oxford: Hadrian Books.

Bowdery, D. 2007. Phytolith analysis, sheep, diet and fecal material at Ambathala pastoral station (Queensland, Australia). In: Madella, M. and Zurro, D. (eds), Plants, Peoples and Places: Recent studies in phytolith analysis, pp. 134-150. Oxford: Oxbow Books.

Bowman, D.M.J.S., Garde, M. and Saulwick, A. 2001. Kunj-ken makka man-wurrk (fire is for kangaroos) landscape burning in central Arnhem land seen through an ethnographic lens. In: Anderson, A., Lilley, I. and O'Connor, S. (eds), Histories of Old Ages: Essays in honour of Rhys Jones, pp. 61-78. Canberra: Pandanus Books. 
Bradstock, R.A., Williams, J.E. and Gill, M.A. 2001. Flammable Australia: The fire regimes and biodiversity of a continent. Cambridge: Cambridge University Press.

British Parliamentary Papers 1970 [1843]. Colonies Australia. Vol. 7. Shannon: Irish University Press.

Bureau of Meteorology 1985. Climatic Statistics for Willunga, Station 023753. Canberra: Commonwealth of Australia.

Charlick, W. 1939. Wheat buying prior to the Australian Wheat Board. Unpublished office records, State library archival collection, Adelaide.

Clark, R. 1982. Point count estimation of charcoal in pollen preparations and thin sections of sediments. Pollen and Spores 24:523-535.

Clifford, H.T. and Watson, L. 1977. Identifying Grasses: Data, methods and illustrations. St. Lucia, Queensland: University of Queensland Press.

Denham, T.P., Haberle, S.G., Lentfer, C.J., Fullagar, R., Field, J., Therin, M., Porch, N. and Winsborough, B. 2003. Origins of agriculture at Kuk Swamp in the Highlands of New Guinea. Science 301:189-193.

Dodson,J.R., de Salis, T., Myers, C.A. and Sharp,A.J. 1994a. A thousand years of environmental change and human impact in the alpine zone at Mt Kosciusko, New South Wales. Australian Geographer 25:77-87.

Dodson, J.R., Roberts, F.K. and de Salis, T. 1994b. Palaeoenvironments and human impact at Burraga Swamp in Montane rainforest, Barrington tops National Park, New South Wales, Australia. Australian Geographer 25:161-169.

Dodson, J.R. and Mooney, S.D. 2002. An assessment of historic impact on southeastern Australian environmental systems, using late Holocene rates of environmental change. Australian Journal of Botany 50:455-464.

Dunstan, M. 1977. Willunga Town and District 1837-1900. Blackwood: Lynton Publications.

Faegri, K. and Iversen, J. 1989. Textbook of Pollen Analysis. New York: Hafner Press.

Finkelstein, S.A. and Davis, A.M. 2005. Modern pollen rain and diatom assemblages in a Lake Erie coastal marsh. Wetlands 25:551-563.

Gale, S.J. and Haworth, R.J. 2002. Beyond the limits of location: human environmental disturbance prior to official European contact in early colonial Australia. Archaeology in Oceania 37:123-136.

Gale, S.J., Haworth, R.J. and Pisanu, P.C. 1995. The ${ }^{210} \mathrm{~Pb}$ chronology of Late Holocene deposition in an Eastern Australian Lake Basin. Quaternary Geochronology 14:395-408.

Gillieson, D, Hope, G. and Luly, J. 1989. Environmental change in the Jimi valley. In: Gorecki, P.P. and Gillieson, D.S. (eds), A Crack in the Spine: Prehistory and ecology of the JimiYuat valley, Papua New Guinea, pp. 105-122. Townsville: Division of Anthropology and Archaeology, James Cook University.

Gott, B. 2005. Aboriginal fire management in south-eastern Australia: aims and frequency. Journal of Biogeography 32:1203-1208.

Haberle, S.G.,Tibby,J.,Dimitriadis, S. and Heijnis, H.2006. The impact of European occupation on terrestrial and aquatic ecosystem dynamics in an Australian tropical rain forest. Journal of Ecology 94:987-1002.

Hallack, E.H.1892. Our Townships and Homesteads: Southern district of South Australia. Adelaide: W.K. Thomas and Co.

Hart, D.M. 1992. A field appraisal of the role of plant opal in the Australian environment. Unpublished Ph.D. thesis, School of Earth Sciences, Macquarie University, Sydney.

Hawker,J.C. 1901. Early Experiences in South Australia, second series. Adelaide: E.S. Wigg and Son.

Haworth, R.J., Gale, S.J., Short, S.A. and Heijnis, H. 1999. Land use and lake sedimentation 
on the New England tablelands of New South Wales. Australian Geographer 30:51-73.

Hobbs, R.J. and Hopkins, A.J.M. 1990. From frontier to fragments: European impact on Australia's vegetation. Proceedings of the Ecological Society of Australia 16:93-114.

Jones, R. 1969. Fire-stick farming. Australian Natural History 16:224-228.

Kershaw, A.P., Bulman, D. and Busby,J.R. 1994. An examination of modern and pre-European settlement pollen samples from southeastern Australia - assessment of their application to quantitative reconstruction of past vegetation and climate. Review of Palaeobotany and Palynology 82:83-96.

Lentfer, C.J. 2006. A simple technology for building large phytolith reference collections from modern plant material. The Phytolitharien 18:1-6.

Lentfer, C.J., Gojak, D. and Boyd, W.E. 1997. Hope Farm windmill: Phytolith analysis of cereals in early colonial Australia. Journal of Archaeological Science 24:841-856.

Lentfer, C.J. and Torrence, R. 2007. Holocene volcanic activity, vegetation succession, and ancient human land use: unravelling the interaction on Garua Island, Papua New Guinea. Review of Palaeobotany and Palynology 143:83-105.

Lewis, A.J.P. 1936. The Official Civic Record of South Australia: Centenary Year, 1936. Adelaide: The Universal Publicity Company.

Linn, R. 1991. Cradle of Adversity: A bistory of the Willunga district. Adelaide: Historical Consultants.

Lunt,I.D. 2002. Grazed, burnt and cleared: how ecologists have studied century-scale vegetation changes in Australia. Australian Journal of Botany 50:391-407.

Mooney, S. 1997. A fine-resolution palaeoclimatic reconstruction of the last 2000 years, from Lake Keilambete, south-eastern Australia. The Holocene 7:139-149.

Newman,L.A.1994.Environmental history of the Willunga Basin 1830s to 1990s. Unpublished BA (Hons) thesis, Department of Geography, University of Adelaide.

Newman, L.A. and Lawrence, R.E. 1999. Hydrological history of the Willunga basin. In: Walker, D. and van der Wel, B. (eds), Living with Water: Scarcity, security, supply, surplus and sustainability, pp. 110-117. Adelaide: Hydrological Society of South Australia.

Northcote, K.H. 1976. Soils. In: Twidale, C.V.R., Tyler, M.J. and Webb, B.P. (eds), Natural History of the Adelaide Region, pp. 61-74. Adelaide: Royal Society of South Australia.

Overton, I.C. 1993. Willunga Basin geographical information systems report. Unpublished report to Willunga Hills Face Land Care Group, Department of Geography, University of Adelaide.

Piperno, D.R., Bush, M.B. and Colinvaux, P.A. 1991. Palaeoecological perspectives on human adaptation in Central Panama. II. The Holocene. Geoarchaeology 6:227-250.

Parr, J.F. 2002. A comparison of heavy liquid flotation and microwave digestion techniques for the extraction of phytoliths from sediments. Review of Palaeobotany and Palynology 120:315-336.

Powers, A.H., Padmore, J. and Gilbertson, D.D. 1989. Studies of late prehistoric and modern opal phytoliths from coastal sand dunes and machair in northwest Britain. Journal of Archaeological Science 16:27-45.

Richardson, A.E.V. 1936. Vines, fruit and forestry. In: Royal Geographical Society of Australasia, South Australian Branch (ed), The Centenary History of South Australia, pp. 163-178. Adelaide: Royal Geographical Society of Australasia, South Australian Branch.

Rockman, M. 2003. Knowledge and learning in the archaeology of colonisation. In: Rockman, M. and Steele, J. (eds), Colonisation of Unfamiliar Landscapes: The archaeology of adaptation, pp. 3-24. London: Routledge.

Rowell, D.L. 1994. Soil Science: Methods and applications. London: Prentice Hall.

Santich, B. 1998. McLaren Vale: Sea and vines. Adelaide: Wakefield Press. 
Specht, R.L. 1972. The Vegetation of South Australia. Adelaide: A.B. James, Government Printer.

Stuart, E. 2005. Cultural landscape change on the Willunga Plains from 1840. Unpublished Honours thesis, Department of Archaeology, Flinders University.

Stuart, E. 2006. Cultural landscape change in the Willunga Basin from European settlement to present. In: Smith, P., Pate, F.D. and Martin, R. (eds), Valleys of Stone: The archaeology and history of the Adelaide's Hills Face, pp. 113-130. Belair (South Australia): Kōpi Books.

Vaudrey, D.P. and Vaudrey, G.C. (eds) 1991. Willunga District: Facts, facets and phases. Two parts. Unpublished manuscript held by authors, Adelaide.

Wallis, L. 2000. Phytoliths, late Quaternary environment and archaeology in tropical semi-arid northwest Australia. Unpublished PhD thesis, Australian National University.

Wallis, L. 2001. Environmental history of northwest Australia based on phytolith analysis at Carpenter's Gap1. Quaternary International 83-85:103-117.

Whitelock, D. 1985. Adelaide from Colony to Jubilee: $A$ sense of difference. Adelaide: Savvas Publishing.

Whitlock, C. and Larson, C. 2001. Charcoal as a fire proxy. In: Smol,J.P., Birks, H.J.B. and Last, W.M. (eds), Tracking Environmental Change Using Lake Sediments. Volume 3: Terrestrial, algal and siliceous Indicators, pp. 75-97. Dordrecht: Kluwer Academic.

Williams, M. 1974. The Making of the South Australian Landscape: A study in the historical geography of Australia. London: Academic Press.

Williams, M. 1992. The Changing Rural Landscape of South Australia. Adelaide: State Publishing.

Young, A.R.M. 1996. Environmental Change in Australia since 1788. Melbourne: Oxford University Press. 